\title{
NILAI BUDAYA PADA LANSKAP INDUSTRI PERKEBUNAN KINA CINYIRUAN BANDUNG pADA MASA KOLONIAL
}

\author{
THE CULTURAL VALUE IN THE LANDSCAPE \\ OF THE CINYIRUAN QUININE PLANTATION INDUSTRY IN BANDUNG \\ DURING THE COLONIAL PERIOD
}

\author{
Lia Nuralia ${ }^{1}$, Iim Imadudin ${ }^{2}$ \\ 1,2, Balai Arkeologi Jawa Barat \\ Jl. Raya Tagog Cinunuk No.KM. 17, Cimekar, Cileunyi, Bandung. \\ 1,2 e-mail: liabalar@yahoo.com, imadudin1975@gmail.com \\ Naskah Diterima: 22 Juli $2021 \quad$ Naskah Direvisi: 13 September $2021 \quad$ Naskah Disetujui : 18 Oktober 2021
}

DOI: $10.30959 /$ patanjala.v13i1.848

\begin{abstract}
Abstrak
Perkebunan Kina Cinyiruan di Bandung telah berdiri sejak tahun 1855. Perkebunan Kina Cinyiruan saat ini telah menjadi kebun afdeeling dari Perkebunan Kertamanah PTPN VIII, sejak digabungkan secara manajerial di masa kemerdekaan. Jejaknya dapat ditelusuri sebagai lanskap budaya industri perkebunan berupa area bekas kebun kina dan permukiman emplasemen, yang mengandung nilai budaya. Apa dan bagaimana nilai budaya tersebut menjadi permasalahan pokok dalam tulisan ini. Metode penelitian adalah desk research dengan pendekatan arkeologi industri serta konsep nilai budaya dan lanskap budaya. Hasil yang diperoleh adalah lanskap budaya industri Perkebunan Kina Cinyiruan memiliki tata guna lahan beragam dengan tinggalan budaya benda beraneka fungsi. Nilai budaya yang terkandung di dalamnya merupakan nilai budaya tradisional Sunda dan nilai budaya kolonial, terkait kearifan lokal dan teknologi modern Barat. Kedua nilai budaya tersebut tampak pada tata letak dan arsitektur bangunan permukiman, serta tata guna lahan area kebun sebagai sistem ekonomi subsistensi dan perkebunan sebagai sistem ekonomi modern Barat yang komersial.
\end{abstract}

Kata kunci: Nilai budaya, lanskap budaya industri, perkebunan kina Cinyiruan.

\begin{abstract}
The Cinyiruan quinine plantation in Bandung has been established since 1855. After the managerial merger during the independence of Indonesia, it is now the government-owned plantation of PTPN VIII Kertamanah. The existence of the plantation can be traced as a cultural landscape of the plantation industry. It includes the area of the former quinine plantation and the emplacement settlement. Both contain cultural values. The main problem in this paper comprise what and how the values are. The research method used is the desk research with an industrial archeology approach and the concept of cultural values and cultural landscapes. The results obtained indicate that the cultural landscape of the Cinyiruan quinine plantation industry has a variety of land uses with cultural relics of various functions. The cultural values contained are the Sundanese traditional cultural values and colonial cultural values which relate to the local wisdom and western modern technology. These two cultural values are traceable in the layout and architecture of residential buildings as well as the land use of the garden area as a subsistence economic system and the plantations as a modern commercial Western economic system.
\end{abstract}

Keywords: cultural values, industrial cultural landscape, Cinyiruan quinine plantation. 


\section{A. PENDAhuluan}

Nilai budaya pada lanskap industri perkebunan kina bukan saja memberi gambaran tentang bentang alam industri perkebunan, tetapi dapat memberi penjelasan tentang nilai budaya perkebunan masa kolonial. Nilai budaya perkebunan merupakan nilai budaya campuran antara budaya Barat dan Timur; antara budaya orang-orang Eropa (Belanda) dan orang-orang Asia (SundaIndonesia). Kedua budaya tersebut bertemu dalam aktivitas industri di perkebunan kina masa lalu, dan di masa sekarang tampak dari lanskap budaya industri yang diwariskannya.

Lanskap budaya industri perkebunan merupakan bentang alam yang ditata, guna memenuhi kepentingan industri perkebunan. Lanskap budaya perkebunan di masa lalu dapat ditelusuri di masa kini melalui jejak lahan dan objek arkeologis kebun dan lahan permukiman emplasemen. Salah satu lanskap budaya industri perkebunan tersebut berada di Afdeling Kebun Cinyiruan, Perkebunan Kertamanah PTPN VIII di Pangalengan Kabupaten Bandung.

Perkebunan Kina Cinyiruan dahulu terpisah secara manajerial dari Perkebunan Kertamanah. Perkebunan ini didirikan oleh Pemerintah Belanda pada pertengahan abad ke-19, tepatnya pada 1855. Pada 1877 didirikan Perkebunan Kina Kertamanah (Kertamanah I $)^{1}$. Kedua perkebunan tersebut memiliki lahan kebun berbatasan. Pada masa sekarang, Perkebunan Cinyiruan menjadi bagian (afdeeling) dari

Gouvernement Kina Onderneming Tjinjiroean (Peta Topografi Blad $32 \mathrm{~B} / \mathrm{Alg}$. No. $X L$ 38-B, 1919 - 1923., n.d.). Kebun Kina Cinyiruan didirikan oleh Pemerintah Belanda 17 Desember 1855 (terpahat di Tugu Peringatan Seratus Tahun Kebun Kina Cinyiruan, Kertamanah, Pangalengan, Bandung, 1995). Perkebunan Kertamanah I, II, III, dan IV (30 Mei 1877; 16 Jan 1884; 12 Feb 1892; 13 Jan 1908; 29 Nov 1911) (Regerings Almanak Voor Nederlandsch-Indie, 1880, 1892, 1893,1900, 1901, 1902, 1906.)
Perkebunan Kertamanah. Penggabungan terjadi di era kemerdekaan dengan alasan efisiensi perusahaan.

Perkebunan Kina Cinyiruan menjadi penting untuk dikaji, erat kaitannya dengan posisi, dan tinggalan budayanya di masa sekarang. Lokasi Perkebunan Kina Cinyiruan memiliki posisi strategis dengan cakupan lahan lebih memungkinkan untuk ditelusuri, dan beragam tinggalan budaya yang ada masih bisa dideskripsikan wujud fisiknya dan menunjukkan sinyal nonverbal (nonfisik/abstrak) sebagai nilai budaya yang terkandung di dalam wujud fisik tersebut. Sementara itu, Perkebunan Kertamanah di masa sekarang memiliki lahan yang sangat luas sebagai hasil dari gabungan beberapa lahan kebun. Keadaan ini akan memerlukan banyak usaha untuk menelusuri jejaknya.

Komoditas Perkebunan Kertamanah sekarang adalah kebun penghasil teh dan kopi, serta aneka tanaman sayur, dan buah, sedangkan kina sudah tidak diproduksi lagi. Berdasarkan hasil penelitian pada 2019 dan informasi dari pihak kebun pada 2021(Ramadhan, wawancara, Maret 2021). Perkebunan Kertamanah merupakan gabungan dari Perkebunan Kertamanah, Perkebunan Cinyiruan, Perkebunan Tirtasari, dan Perkebunan Cikembang. Perkebunan Kertamanah sekarang sebagai kebun induk memiliki enam afdeling, yaitu Kertamanah, Cinyiruan, Puncak Gedeh, Wayang, Tirtasari, dan Cikembang (Nuralia, 2019: 33).

Sebagian lahan bekas Perkebunan Kina Cinyiruan, sekarang sudah ditanami kopi dan teh, tetapi satu dua pohon kina (Chincona sucirrubra dan Chincona ledgeriana) masih tampak di lahan yang belum dialihfungsikan. Sementara itu, bangunan atau struktur bangunan lama yang masih ada sebagian tetap dipertahankan dan digunakan. Sebagian bangunan lainnya dibiarkan begitu saja. Ada pula bangunan yang sudah hancur karena usia atau sengaja dihancurkan, dan di atasnya didirikan bangunan baru atau dibiarkan menjadi lahan kosong. 
Tata guna lahan bekas Perkebunan Cinyiruan beraneka ragam, dan mengalami perubahan fungsi seiring perkembangan zaman. Perubahan yang terjadi dalam periode waktu tertentu telah melahirkan budaya khas perkebunan yang terus berkembang. Bekas lahan perkebunan tersebut menjadi lanskap budaya industri perkebunan yang bernilai sejarah. Lanskap budaya industri perkebunan juga memberi petunjuk tentang nilai-nilai budaya perkebunan. Apa dan bagaimana nilai budaya perkebunan masa kolonial apabila ditelusuri dari lanskap budaya industri perkebunan tersebut, akan menjadi permasalahan pokok dalam tulisan ini.

Nilai budaya dalam sistem budaya merupakan lapisan yang paling abstrak dan luas ruang lingkupnya. Nilai adalah ukuran baik dan buruk, memiliki fungsi memantapkan dan menstabilkan kebudayaan (Foster, 1975). Perbedaan nilai-nilai dapat disebabkan oleh dua faktor, yaitu perbedaan ruang dan waktu. Misalnya budaya Barat dan budaya Timur memiliki nilai-nilai yang berbeda, karena orang Barat memiliki ruang yang berbeda dengan orang Timur. Kemudian perbedaan nilai juga terjadi karena perbedaan waktu seiring perkembangan zaman. Pada zaman dahulu nilai tertentu memiliki makna tinggi, tetapi menjadi turun atau tidak bernilai di masa sekarang. Perbedaan nilai budaya tersebut akan berpengaruh kepada berbagai bidang kehidupan, salah satunya terhadap sistem ekonomi dan sistem sosial yang dianut oleh suatu negara atau sekelompok manusia.

Sistem perkebunan merupakan sistem perekonomian pertanian komersial (commercial agriculture) bercorak kolonial, bersandar pada sistem perkebunan Eropa (european plantation). Ciri-ciri utama sistem perkebunan, yaitu bentuk usaha pertanian berskala besar dan kompleks; bersifat padat modal (capital intensive); lahan luas; organisasi tenaga kerja besar; pembagian kerja rinci; tenaga kerja upahan (wage labour); struktur hubungan kerja rapih; teknologi modern; spesialisasi; sistem administrasi dan birokrasi; serta tanaman komersial (commercial crops) komoditas ekspor. Keadaan ini berbeda dengan sistem kebun yang tradisional dengan ekonomi subsisten, tidak padat modal, dan tidak berorientasi ekonomi (Kartodirdjo \& Surjo, 1991: 3-4).

Lanskap budaya (cultural landscape) merupakan suatu bentukan lanskap masa lampau yang memiliki dimensi waktu di dalamnya (Nurisjah \& Pramukanto, 2001), hasil interaksi antara manusia dengan sistem alam, dalam rentang waktu panjang. Suatu bentukan lanskap dikatakan memiliki nilai sejarah apabila memiliki minimal satu kriteria. Ada tiga kriteria yang mendukung suatu bentukan lanskap, yaitu: (1) etnografis, merupakan produk khas suatu sistem ekonomi dan sosial suatu kelompok/suku masyarakat (etnik); (2) associative, suatu bentuk lanskap yang berasosiasi atau yang dapat dihubungkan dengan suatu peristiwa, personal, masyarakat, legenda, pelukis, estetika dan sebagainya; dan (3) adjoining, adalah bentukan lanskap bagian dari suatu unit tertentu, bagian monumen, atau bagian dari struktur bangunan tertentu. Selanjutnya dijelaskan bahwa lanskap budaya juga merupakan lanskap sejarah, lanskap yang berasal dari masa lampau, dan di dalamnya terdapat bukti fisik tentang keberadaan manusia pendukung budaya tersebut (Harvey dan Buggey, 1988).

Lanskap budaya atau cultural landscape disebut juga dengan istilah "saujana budaya". Istilah "saujana budaya" merupakan satu konsep yang telah diterima secara luas dan diadopsi dalam kriteria World Heritage sejak tahun 1973. UNESCO World Heritage Centre pada tahun 2005 menjelaskan bahwa "saujana budaya" sengaja dirancang oleh manusia, terbentuk secara perlahan dan bertahap, hasil dari interaksi manusia dengan alam (baik yang sudah menjadi relik maupun yang masih terus berproses). Saujana budaya asosiatif selalu dikaitkan dengan 
gagasan religius, tradisi, atau pemahaman budaya tertentu atau terkait unsur budaya tak benda (intangible) (Lanskap Budaya, 2018).

\section{B. METODE PENELITIAN}

Penelitian situs perkebunan termasuk penelitian arkeologi industri (industrial archaeology) (Casella, 2005: 15). Tulisan ini berdasarkan hasil penelitian arkeologi industri tahun 2019, dengan framework: surface surveys, excavations, archival research; dan oral history interviews (Palmer \& Neaverson, 2000: 15); dan diperkaya dengan sumber data hasil survei tahun 2021. Metode penelitian dalam tulisan ini adalah desk research terhadap laporan hasil penelitian arkeologi, jurnal ilmiah, buku, serta sumber arsip kolonial ketika penulisan dilakukan di tahun 2021. Tulisan ini menggunakan konsep nilai budaya dan konsep lanskap budaya.

Langkah-langkah pengkajian yang dilakukan sebagai berikut.

- Menetapkan objek arkeologis yang akan dijadikan sumber data;

- Melakukan deskripsi terhadap objek arkeologis mengenai wujud fisik dan tata letaknya dalam lanskap kebun dan emplasemen permukiman;

- Mencari sumber arsip terkait sejarah perkebunan dan lay out kawasan kebun dan emplasemen lama;

- Mencari pengertian konsep yang digunakan; dan

- Melakukan analisis bentuk wujud fisik, memahami simbol atau sinyal nonverbal (bahasa nonverbal) yang ditunjukkan, dan interpretasi terhadap wujud fisik sehingga dapat menjelaskan nilai budaya yang terkandung di dalamnya.

\section{HASIL DAN BAHASAN}

Perkebunan kina Cinyiruan terletak di Bandung Selatan dengan fisiografi didominasi lahan perbukitan dan pegunungan. Karakter lingkungan seperti ini sangat cocok untuk tumbuh kembang pohon kina. Perkebunan ini merupakan perusahaan besar milik negara, Gouvernement Kina Onderneming Tjinyiroean yang didirikan 17 Desember 1855 (Nuralia et.al, 2019: 215).

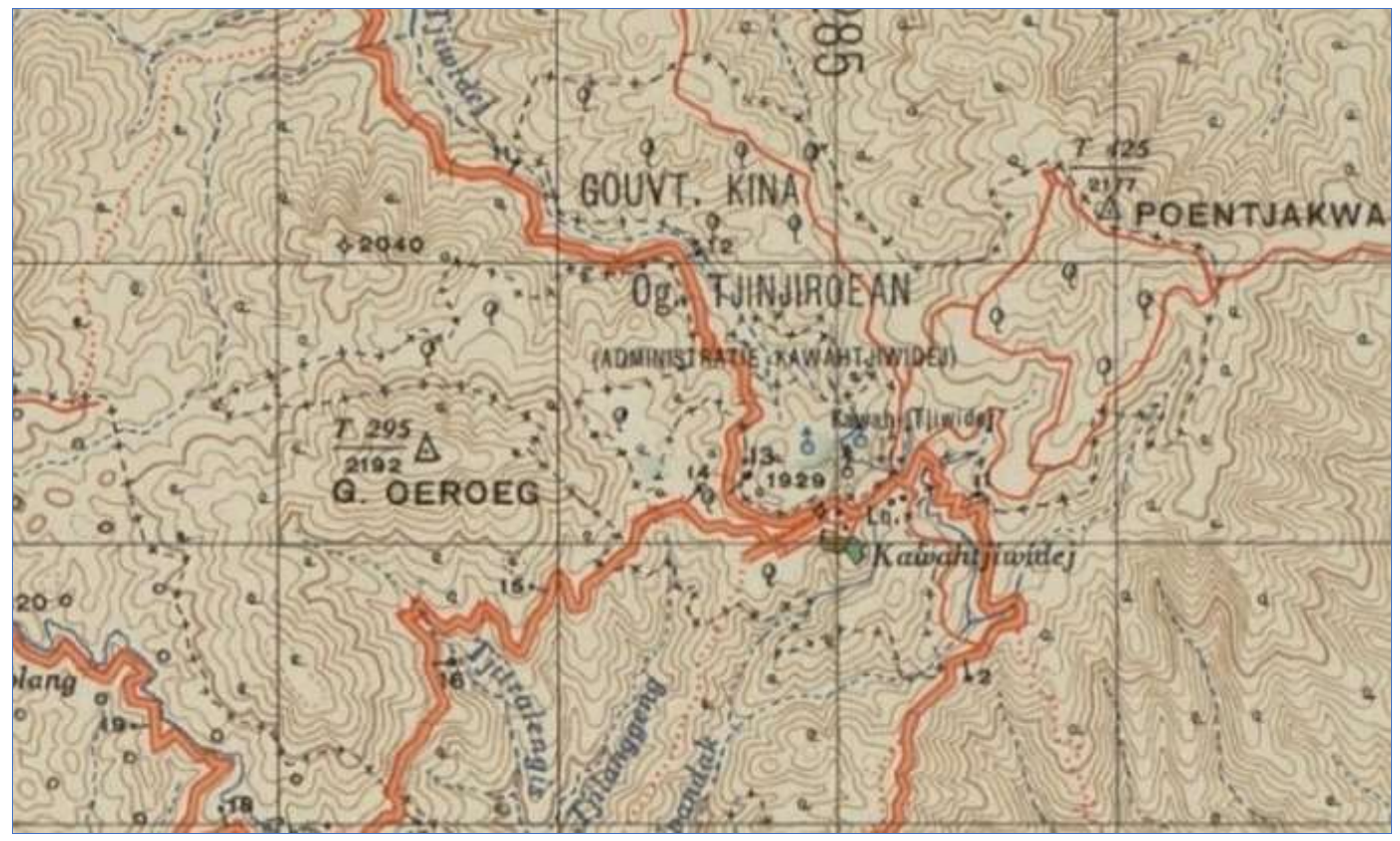

Gambar 1. Perkebunan Cinyiruan (Gouvt. Kina Og. Tjinjiroean)

Sumber: Peta Topografi Blad 32 B (Alg. No. XL 38-B) Java. Res. Preanger Regentschappen. Topografischen Dienst in 1919 - 1923. Dutch Colonial Maps - Leiden University Libraries. 
Permukiman emplasemen perkebunan didirikan pada pedataran lereng atau puncak yaitu bukit, dan lembah. Bukit, lereng, dan lembah tersebut merupakan lahan luas di gunung-gunung yang masih aktif dahulunya, bahkan ada yang masih menunjukkan keaktifannya sampai sekarang.

Salah satu puncak gunung api di Bandung Selatan, di Kecamatan Pangalengan di bagian timur adalah Gunung Malabar (2.321 m dpl). Kawasan lahan di sebelah selatan Gunung Malabar terdapat Gunung Wayang $(2.182 \mathrm{~m} \mathrm{dpl})$ dan Gunung Windu $(2.054 \mathrm{~m} \mathrm{dpl})$ (Peta Topografi sheet, 1944). Daerah pegunungan ini tersusun oleh batuan gunung api muda. Kawasan di antara puncak-puncak gunung merupakan Dataran Pangalengan. Lahan di tengahtengah Dataran Pangalengan terdapat danau (situ) bernama Situ Cileunca. Dataran Pangalengan ini tersusun oleh endapan piroklastika yang sangat tebal (Nuralia et.al, 2019). Kemudian kawasan permukiman emplasemen perkebunan Cinyiruan juga berada di antara sungai kecil, yaitu Sungai Cihejo yang berhulu di lereng timur Gunung Malabar, cabang dari sungai besar Citarum. Kawasan di bagian tengah terdapat aliran Cisangkuy yang berhulu di Situ Cileunca, mengalir ke utara di sebelah barat Gunung Malabar (Nuralia et.al, 2019: 118-121).

Lokasi Kebun Cinyiruan berada di daerah pedalaman dengan topografi lahan tidak rata atau bergelombang (Gambar 1). Lahan seperti ini memberi efek persediaan air yang tidak tetap. Keadaan topografi secara tidak langsung berperan dalam pengembangan profil tanah dan memengaruhi persediaan air, yang dapat digunakan untuk pertumbuhan tanaman. Selain itu, juga memengaruhi nilai pertanian tanah, sehingga berkaitan dengan drainase luar dan dalam, serta kemudahan melaksanakan pengerjaan pembajakan (Foth, 2010: 211).

Perkebunan Cinyiruan merupakan perusahaan perkebunan milik pemerintah
Belanda ketika pertama kali didirikan di tahun 1855. Sistem perkebunan merupakan sistem ekonomi modern berpadu dengan sistem ekonomi tradisional. Sistem ekonomi modern berasal dari budaya Barat yang dibawa oleh Belanda (Eropa) yang menjadi pengelola dan pemilik perkebunan, sedangkan budaya Timur (Asia) adalah budaya para pekerja kebun berasal dari pribumi asli Indonesia (etnis Sunda). Kedua budaya bercampur dalam satu komunitas dengan sistem ekonomi berbeda.

Sistem ekonomi modern diterapkan ke dalam perkebunan dalam skala besar dengan komoditas tanaman pertanian komersial, sedangkan sistem ekonomi tradisional merupakan sistem ekonomi subsistensi, berjalan dalam keseharian para pekerja perkebunan. Para pekerja atau kuli kebun menggarap sawah dan ladang serta beternak untuk memenuhi kebutuhan pangan sehari-hari (Nuralia, 2016). Dengan Demikian, dalam komunitas perkebunan terjadi dualisme ekonomi seperti yang dikemukakan J.H. Boeke. Hasil sistem kebun masuk sektor ekonomi subsistensi, sedangkan hasil agro industri masuk sektor ekonomi Barat (Boeke, 1983). Hasil kebun adalah garapan mandiri para pekerja berupa lahan sawah, lahan kebun sayur dan palawija, serta ternak. Sebagian besar hasil kebun dikonsumsi sendiri dan ada sebagian kecil lainnya dijual di pasar lokal. Kemudian lahan hasil agro industri (perkebunan) di antaranya kopi, kina, teh, karet, dan kelapa sawit, yang merupakan komoditas perdagangan dunia internasional (ekspor).

Sistem ekonomi modern melahirkan sistem ekonomi uang, sebagai jelmaan sistem ekonomi liberal (Barat) beserta kapitalismenya. Sistem ini secara perlahan dan terus menerus menunjukkan garis progresif terhadap pertanian di Pulau Jawa dan sebagian wilayah utara Pulau Sumatra (Sajogyo, 1982: 7). Upah buruh perkebunan dibayar dengan uang. Alat tukar berupa uang sudah semakin popular dalam masyarakat perkebunan, walaupun 
sistem barter masih berlangsung di antara para pekerja perkebunan. Lahan perkebunan sudah ditentukan lokasi dan luasnya dengan penataan berteknologi modern, disesuaikan dengan lingkungan alam pegunungan, beriklim tropis basah.

Lahan adalah tanah yang digunakan untuk usaha pertanian atau perkebunan. Penggunaan lahan sangat tergantung kepada keadaan dan lingkungan lahan berada (Daniel, 2004: 66). Struktur tanah yang baik untuk penanaman kina adalah subur, gembur, banyak mengandung bahan organik, tidak bercadas dan tidak berbatu, memiliki derajat keasaman $(\mathrm{pH})$ antara 4,6 - 6,5 dengan $\mathrm{pH}$ optimum 5,8, serta ketinggian tempat di antara $800-2.000$ meter, dengan ketinggian optimum 1.400 $1.700 \mathrm{~m}$ dpl (Nuralia et.al, 2019).

Area bekas kebun kina dan permukiman emplasemen Perkebunan Kina Cinyiruan menunjukkan lanskap budaya industri dengan pembagian lahan sesuai kebutuhan perusahaan perkebunan.
Lahan ditandai dengan bangunan industri untuk produksi utama, pendukung produksi, dan permukiman para pengelola dan pekerja kebun. Tampak dalam denah lanskap Permukiman Emplasemen Perkebunan Cinyiruan Masa Kolonial (Gambar 2) ada pembagian lahan, yaitu: (1) lahan perkantoran dan fasilitas sosial atau fasilitas umum, (2) pemukiman pekerja, (3) lahan pabrik kina \& bangunan pendukung produksi, serta (4) lahan khusus untuk rumah pengelola perkebunan yang terpisah sendiri, berada di antara pabrik, kantor, dan kebun.

Hasil survey tahun 2019 (Nuralia et.al, 2019: 30-34, 89) dan 2021, Emplasemen Cinyiruan Perkebunan Kertamanah (Gambar 3), masih memiliki tinggalan budaya lama, sebagai berikut.

1. Rumah Dinas Asisten Afdeling Tirtasari

2. Kantor Afdeling Cinyiruan

3. Lapangan Tenis Cinyiruan

4. Lapangan Bola

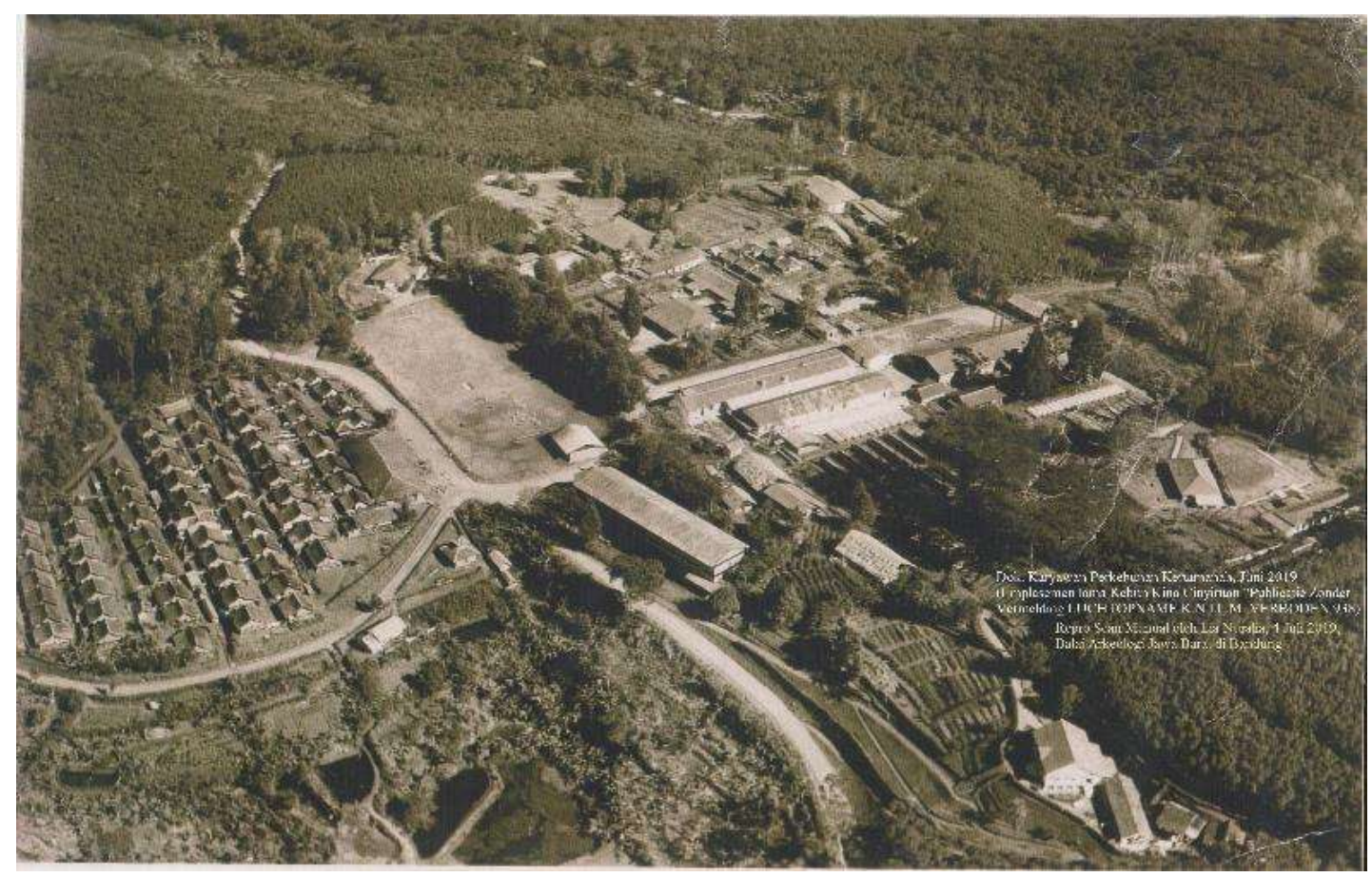

Gambar 2. Denah Lanskap Permukiman Emplasemen Perkebunan Cinyiruan Masa Kolonial Tampak dari Rumah ADM

Sumber: Nuralia et.al, 2019; Modifikasi Lia Nuralia, 2021. 


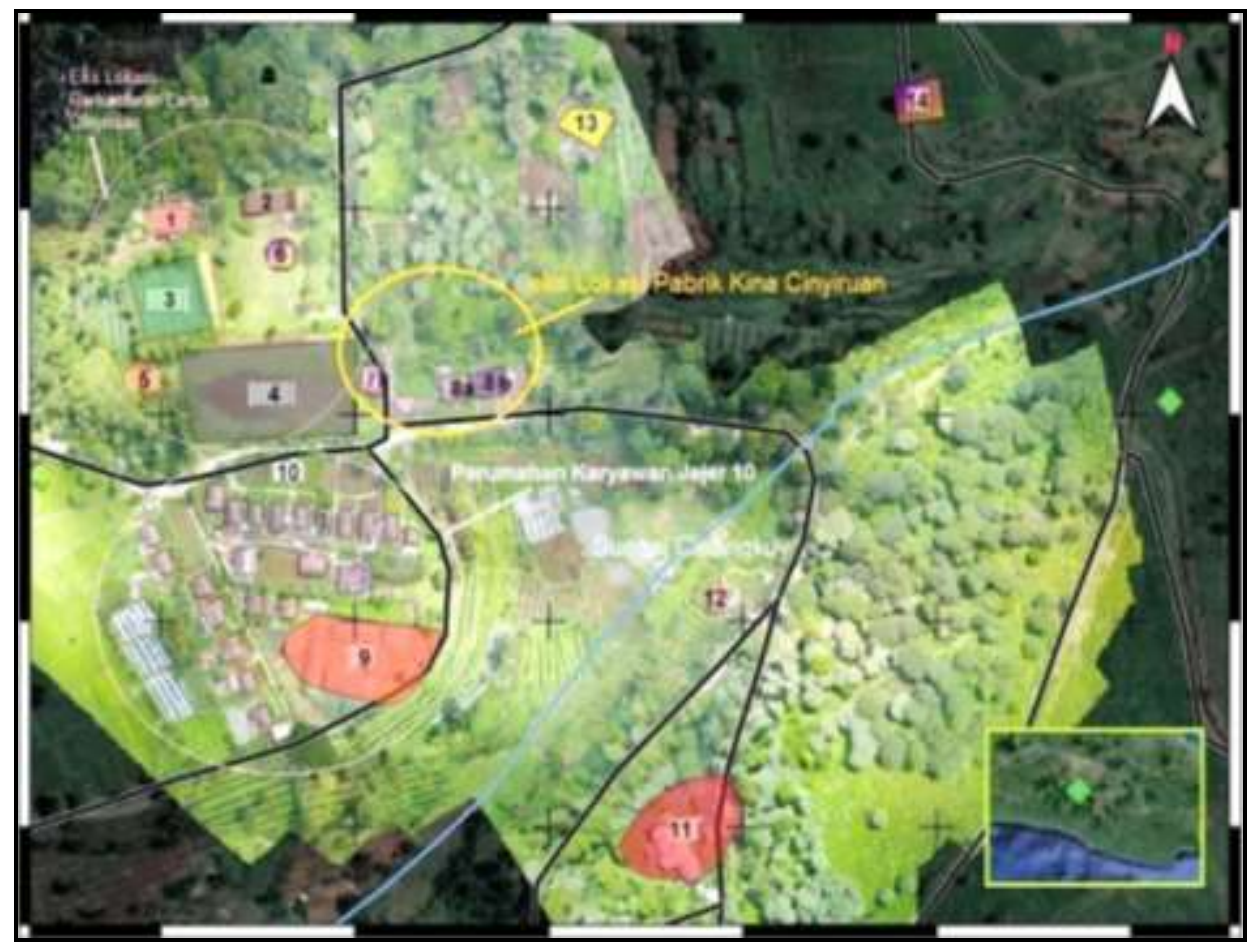

Gambar 3. Emplasemen Permukiman Afdelin Kebun Cinyiruan Perkebunan Kertamanah Sumber: Laporan Penelitian Arkeologi, 2019.

5. Bekas Madrasah (Bekas Rumah Dinas Mandor Besar Cinyiruan)

6. Tugu Peringatan 100 Tahun Kebun Cinyiruan

7. Bekas PLTM Cinyiruan

8. Posyandu Aster 21 dan Rumah Karyawan (Bekas Komplek Pabrik Kina Cinyiruan)

9. SDN Cibeureum

10. Bekas lokasi Pasar Cinyiruan

11. Rumah Dinas ADM Kertamanah (Bekas Rumah ADM Cinyiruan)

12. SDN Campaka

13. Rumah Dinas Asisten Afdeling Cinyiruan (bekas Rumah Tinggal Gerald Alfred Cup, Botanis dan Administratur Kebun Cinyiruan tahun 1945 - 1970-an)

14. Makam Gerald Alfred Cup (Tuan Keub/Tuan Cup).

Tinggalan budaya tak benda di Kebun Cinyiruan berupa tradisi produksi dan nilai budaya perkebunan, yang diperoleh dari hasil wawancara dengan informan (Hidayat, wawancara, 2018;
Hidayat, wawancara, 2019). Tradisi produksi di sini adalah proses produksi pengolahan kina dari mulai pengadaan kulit kina basah di kebun dan pengolahan kulit kina kering di pabrik. Langkahlangkah pengolahan tersebut menjadi tinggalan budaya tak benda (intangible culture) yang memiliki nilai-nilai budaya khas perkebunan. Nilai budaya khas perkebunan merupakan budaya hybrid, campuran antara budaya Barat dan budaya Timur (Nuralia dan Imadudin, 2019).

Nilai budaya Barat berjalan beriringan dengan nilai budaya Timur, karena tidak pernah benar-benar terjadi percampuran antara kedua budaya tersebut. Pertemuan dua budaya terlihat dari bentuk dan gaya arsitektur rumah tinggal. Unsur arsitektur Eropa dipadu dengan unsur arsitektur lokal, yaitu dinding tebal dengan plester semen yang menggunakan teknologi modern, berpadu dengan bentuk atap bahan isian dinding yang digunakan adalah bata merah dari tanah liat bakar dan batu alam (andesit). Bentuk atap lebih menunjukkan ciri arsitektur lokal (Sunda), 
yaitu atap jolopong (kampung) dan parahu kumereb (limasan). Keadaan ini tampak pada rumah pejabat tinggi perkebunan, seperti rumah administratur, rumah sinder afdeling, dan jajaran rumah pengelola lainnya yang diperuntukkan bagi orangorang Eropa.

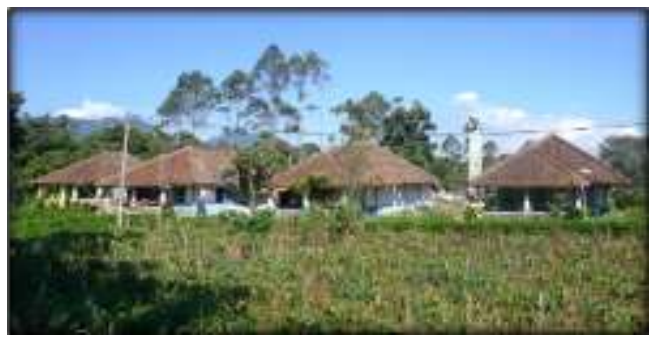

Gambar 4. Perumahan Karyawan Jejer 10 Kebun Cinyiruan

Sumber: Dokumentasi Iim Imadudin, 2021.

Pertemuan antara budaya Barat dan Timur juga tampak pada perumahan pegawai yang secara wujud fisik banyak mengadopsi bentuk rumah panggung (Gambar 4). Bahan dinding dan atap juga terbuat dari bahan kayu dan ijuk, yang menjadi penanda rumah tradisional Sunda. Unsur budaya Barat ditunjukkan dengan tata letak dalam ruang yang khas alam pegunungan, dengan ketinggian lahan tidak rata. Penataan lahan perumahan pegawai di alam hutan hujan tropis berbeda dengan penataan lahan bangunan dalam penataan rumah tradisional Sunda. Hutan yang telah dibuka untuk lahan pemukiman kemudian ditata dengan cara cut and fill. Lahan diratakan dan disesuaikan dengan jarak antarrumah yang sama, serta lahan yang datar dan tertata rapih.

Bangunan rumah administratur atau manajer perkebunan (Gambar 5) dan rumah karyawan berbeda secara fisik, berdasarkan kriteria model bangunan dan penyebutan rumah dan perumahan. Rumah ADM bermodel rumah nonpanggung, sedangkan rumah pekerja bermodel rumah panggung. Penyebutan rumah untuk bangunan pejabat tinggi sebagai bangunan tunggal. Sementara itu, rumah karyawan disebut perumahan, sekelompok rumah dengan model dan dimensi yang hampir sama. Model rumah nonpanggung identik dengan rumah modern Barat, dengan bahan bangunan dan teknologi modern, walaupun unsur tradisional (timur) atau lokal masih dipergunakan sebagai penyesuaian dengan lingkungan alam sekitar. Kemudian model rumah panggung menyerupai rumah tradisional Sunda, dengan sentuhan unsur teknologi Barat dalam penataan lahan bangunan (Nuralia, et.al, 2019: 101-102).

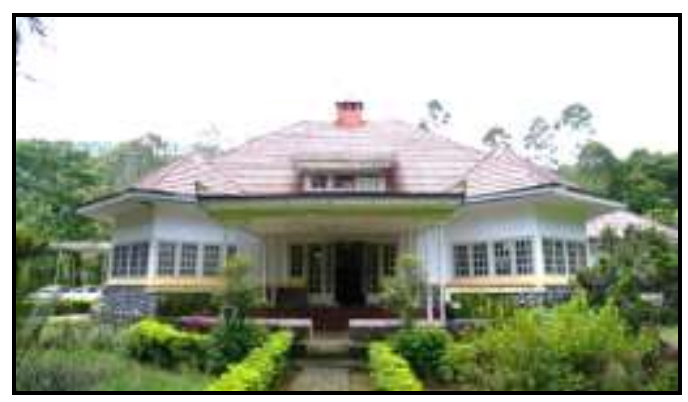

Gambar 5. Rumah Manajer/ADM Perkebunan Kertamanah.

Sumber: Dokumentasi Iim Imadudin, 2021.

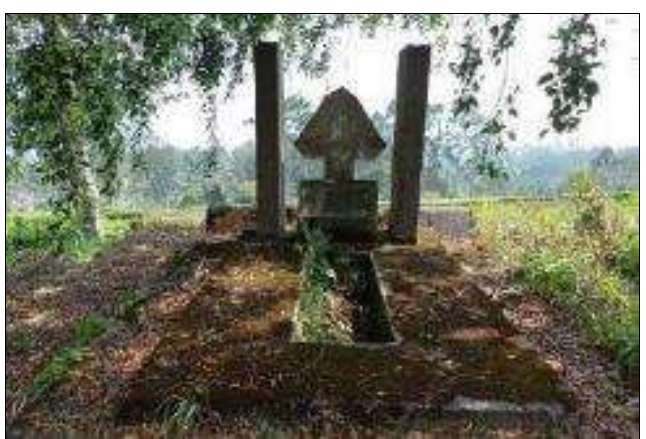

Gambar 6. Makam Gerald Alfred Cup di Bekas Lahan Kebun Kina Cinyiruan Sumber: Dokumentasi Iim Imadudin, 2021.

Lahan permukiman perkebunan juga menyediakan lahan kuburan atau pemakaman umum. Biasanya digunakan untuk para pekerja atau karyawan kebun. Kemudian lahan kuburan khusus disediakan untuk para pejabat tinggi perkebunan. Salah satu lahan khusus makam ditemukan di bekas Kebun Kina Cinyiruan, di lahan datar di lereng bukit Kebun Kina. Ada satu makam dengan 
penanda salib di bawah pohon beringin dan dikelilingi pohon kina, yaitu makam Gerald Alfred Cup, seorang botanis dan Administratur Perkebunan Kina Cinyiruan terakhir. Ia dikenal sebagai Meneer Cup atau Tuan Kap (Gambar 6).

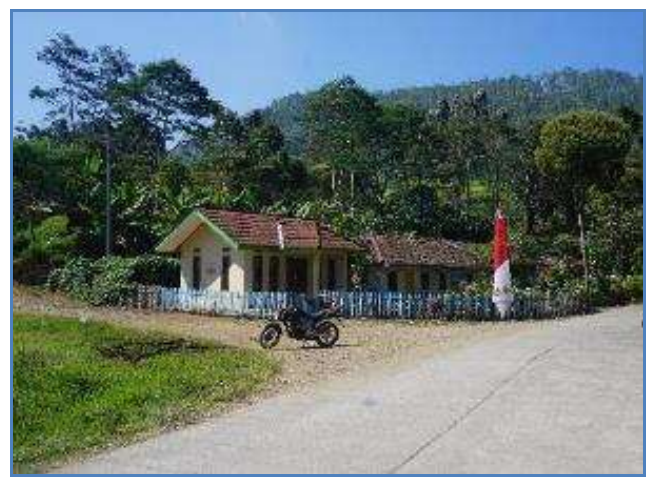

Gambar 7. Bekas Lahan dan Sisa Fondasi Pabrik Kina Cinyiruan

Sumber: Dokumentasi Iim Imadudin, 2021.

Tata guna lahan dalam lanskap budaya industri perkebunan kina memiliki keterkaitan dengan fungsi bangunan yang didirikan di atasnya. Lahan produksi menjadi tempat berdirinya pabrik sebagai bangunan produksi utama dan bangunan pendukung produksi (Gambar 7). Letak pabrik dan bangunan pendukung produksi akan berdekatan karena ada hubungan formal di antara keduanya. Misalnya PLTM (kantor, turbin, bak air) memiliki hubungan formal sangat jelas dengan Pabrik Kina, karena pabrik pengolahan kulit kina kering dapat beroperasi apabila ada pendukung energi listrik untuk menghidupkan mesin penggilingan (Nuralia, et.al, 2019: 98).

Berdasarkan bentuk, arsitektur dan tata letak bangunan rumah tinggal tersebut, tampak adanya perpaduan serasi antara nilai budaya Barat dan Timur. Kemudian tampak juga adanya perbedaan yang kontras yang menunjukkan fungsi rumah terkait peran (status) dan jenis pekerjaannya. Pada masa kolonial, struktur sosial masyarakat perkebunan terbagi menjadi dua bagian besar, yaitu pemilik dan pekerja atau antara majikan dan buruh (Nuralia, 2016). Majikan berasal dari orang-orang Eropa (Belanda) dan buruh adalah orang-orang pribumi asli Indonesia (Sunda). Dengan demikian, masyarakat perkebunan secara kontras terdiri dari dua ras, yaitu ras Eropa dan ras Asia dengan budaya Barat dan Timur. Budaya yang berbeda melahirkan sistem nilai yang berbeda pula. Akibat dari keadaan kontras dalam kehidupan sosial di perkebunan tersebut menunjukkan sistem sosial yang bersifat dualisme, yaitu sistem sosial tradisional Timur dan sistem sosial modern Barat.

Keberadaan sistem ekonomi dan sistem sosial yang bermuka dua membuktikan lanskap Kebun Cinyiruan memiliki kriteria sebagai lanskap budaya industri yang bernilai sejarah. Lanskap tersebut sengaja dibentuk oleh Pemerintah Kolonial berkaitan dengan kolonialisme dan imperialisme orang-orang Eropa di tanah jajahannya. Salah satu bukti penjajahan yang paling konkret adalah adanya pemerasan sumber daya alam dan sumber daya manusia melalui pendirian perusahaan pekebunan.

Dualisme ekonomi perkebunan menunjukkan adanya kriteria etnografis khas perkebunan. Kriteria etnografis merupakan produk khas suatu sistem ekonomi dan sosial suatu kelompok/suku masyarakat (etnik). Dalam hal ini adalah etnis Sunda sebagai kelompok besar manusia yang terlibat dalam perputaran ekonomi Pemerintah (penjajah) Belanda. Sementara itu, orang-orang Belanda sebagai bangsa pendatang berhasil menguasai sumber alam dan sumber daya manusia pribumi (yang dijajah). 

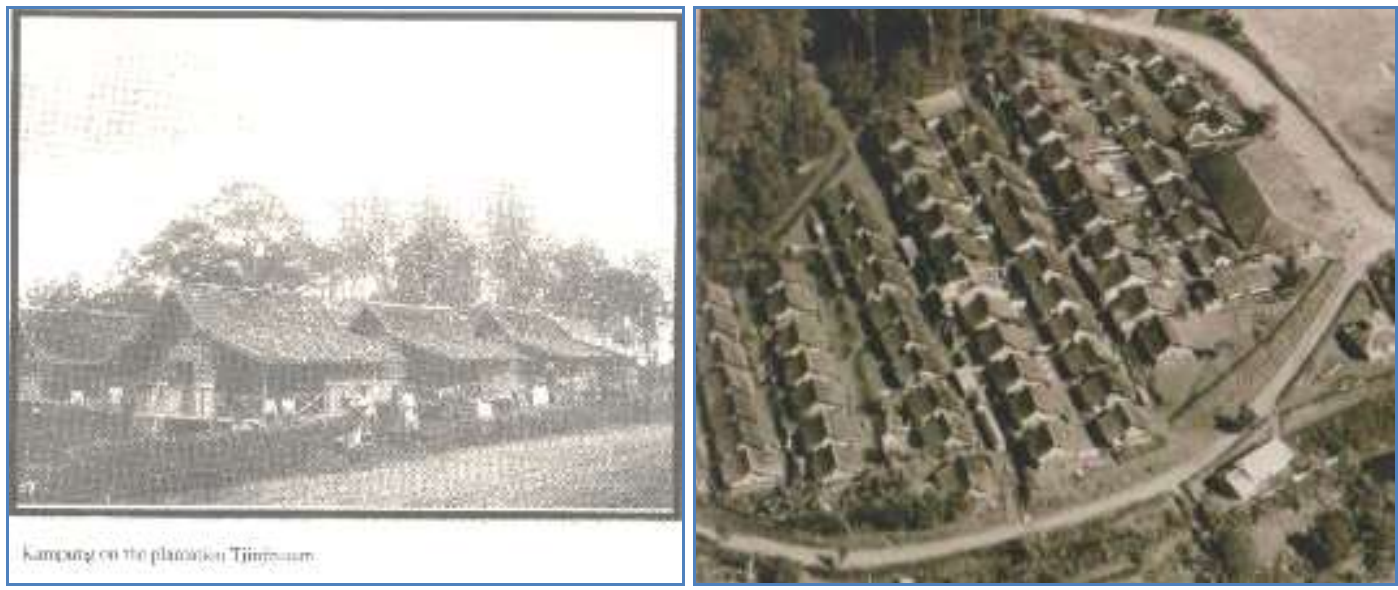

Gambar 8. Perumahan karyawan "Jejer Sapuluh" Kebun Cinyiruan Lama

Sumber: Publicatie Zonder Vermelding LUCHTOPNAME K.N.I.L.M. VERBODEN 938 dan Dokumentasi Karyawan Perkebunan Kertamanah (Repro/Scan Manual oleh Lia Nuralia, 4 Juli 2019)

Lanskap industri perkebunan juga menunjukkan adanya kriteria asosiatif. Suatu bentuk lanskap yang berasosiasi atau yang dapat dihubungkan dengan suatu peristiwa, personal dan masyarakat. Dalam kasus Kebun Kina Cinyiruan, peristiwa besar itu terjadi pada pertengahan abad ke19 atau tahun 1855 , ketika pertama kali Kebun Cinyiruan didirikan oleh Pemerintah Belanda. Pendirian Perkebunan Cinyiruan merupakan salah satu peristiwa penting yang berdampak besar kepada perkembangan ekonomi Hindia Belanda dan perubahan nilai budaya, yaitu lahirnya budaya khas masyarakat perkebunan dengan nilai-nilai budaya hibrid. Budaya hibrid ketika itu ditunjukkan dengan adanya penyebutan budaya indis, yang lahir dalam berbagai ruang kolonial, di kota-kota dan di desa-desa (Soekiman, 2011), termasuk di desa pegunungan tempat berdirinya perkebunan.

Kebun Afdeling Cinyiruan sebagai lanskap budaya industri perkebunan yang bisa juga disebut sebagai "saujana budaya", bersifat asosiatif karena terkait dengan keragaman budaya, tradisi budaya lokal Sunda, yang terkait unsur budaya tak benda atau intangible culture. Kebun Afdeling Cinyiruan juga merupakan bentukan lanskap bagian dari suatu persekutuan besar pemerintah kolonial dalam sistem ekonomi kolonial, yang berasal dari masa lampau, dengan bukti fisik tentang keberadaan manusia berupa lahan kebun, dan lahan emplasemen permukiman yang di atasnya masih tersisa bangunan lama dan sisa-sisanya. Dengan demikian, lahan kebun dan emplasemen permukiman Cinyiruan memiliki sifat adjoining.

Lanskap budaya industri Perkebunan Cinyiruan dengan tiga kriteria tersebut melahirkan nilai-nilai budaya campuran antara budaya Barat dan budaya Timur. Nilai budaya dalam sistem budaya merupakan lapisan yang paling abstrak dan luas ruang lingkupnya, terkait erat dengan ukuran baik dan buruk, serta memiliki fungsi memantapkan dan menstabilkan kebudayaan. Ada dua nilai budaya secara garis besar yang tumbuh dalam masyarakat Perkebunan Kina Cinyiruan masa kolonial, yaitu:

1. Nilai budaya kolonial; dan

2. Nilai budaya tradisional Sunda.

Kedua nilai budaya tersebut berkaitan erat dengan kearifan lokal dan sisi positif kolonialisme Barat di Indonesia, melalui lanskap industri perkebunan warisan kolonial Belanda. 


\section{Nilai Budaya Tradisional Sunda \\ Berpadu dengan Nilai Budaya \\ Kolonial Barat dalam Lanskap \\ Budaya Industri Perkebunan}

Nilai budaya tradisional Sunda tampak pada perumahan karyawan (pegawai) perkebunan secara wujud fisik bangunan dan tata letak bangunan atau pola pemukiman. Kemudian nilai budaya lainnya tampak pada tata guna lahan dalam pemenuhan kebutuhan pangan berupa kebun, ladang, dan sawah.

Wujud fisik bangunan rumah orang Sunda adalah model rumah panggung dengan bentuk atap di antaranya joloppong (kampung), parahu kumereb (limasan), dan julang ngapak (model kampung dengan ujung melebar dan menekuk). Kemudian bahan lantai, bahan dinding, dan penutup atap memanfaatkan potensi alam di lingkungan pegunungan. Penampakan fisik tersebut menjadi ciri menonjol yang tampak kasat mata. Ciri rumah tradisional Sunda dengan bentuk atap julang ngapak tampak pada perumahan karyawan Perkebunan Cinyiruan dahulu (Gambar 8). Sementara itu, perumahan karyawan emplasemen permukiman Afdeling Cinyiruan Perkebunan Kertamanah sekarang memiliki bentuk atap perpaduan bentuk atap jolopong dan parahu kumereb.

Adopsi model rumah panggung memanfaatkan budaya lokal dan ketersediaan di lingkungan setempat, menjadi pilihan kaum koloni. Dalam hal ini adalah budaya Sunda di dataran Pangalengan, Priangan Jawa Barat. Model rumah panggung tersebut merupakan salah satu kearifan lokal dalam pemenuhan kebutuhan akan tempat tinggal yang sesuai dengan kondisi alam pegunungan di Priangan dengan iklim tropis basah. Model rumah panggung juga memiliki makna dan filosofi tersendiri bagi masyarakat Sunda. Konsep filosofi ini yang tidak ditemukan pada perumahan karyawan perkebunan, sehingga tidak identik dengan penjelmaan rumah tradisional Sunda.
Rumah Panggung tradisional Sunda menunjukkan kearifan lokal, memiliki makna sebagai berikut: (1) bahan yang digunakan sesuai iklim tropis basah Indonesia; (2) posisi lantai tidak menempel ke permukaan tanah, sehingga rumah tidak menjadi lembab; (3) penghuni tidak berada di permukaan tanah, tetapi di tengahtengah sehingga tidak langsung merasakan udara dingin (Nuralia, 2020: 85).

Secara fisik ada kesamaan antara keduanya, yaitu memiliki lantai berada di atas tanah, ada ruang antara permukaan tanah dan lantai rumah atau berkolong (Nuryanto dan Ahdiat, 2014). Persamaan lain yang juga tampak mirip pada bahan bangunan yang digunakan. Bahan dinding bilik bambu, rangka kayu, lantai papan atau palupuh, serta penutup atap dari ijuk atau daun-daun kering. Kemudian terjadi perkembangan lain dengan sentuhan budaya Barat, yaitu bahan penutup atap memakai genteng tanah liat.

Filosofi model rumah panggung tradisional Sunda menjadi perbedaan menonjol antara keduanya. Tampak dalam pembagian ruang, struktur bangunan, dan tata letak dalam lanskap ruang permukiman (Tabel 1). Rumah tradisional Sunda memakai konsep Tri Tangtu. Kata Tri artinya tiga dan kata Tangtu artinya pasti. Pemahaman konsep Tri Tangtu bahwa dunia terbagi menjadi tiga bagian, yaitu ambu handap (dunia bawah), ambu tengah (dunia tengah), dan ambu luhur (dunia atas) (Danasasmita, et.al, 1987). Kemudian pembagian ruang dibagi tiga, yaitu (1) tepas (teras/ruang terbuka) untuk menerima tamu, sebagai ruang laki-laki, (2) tengah imah (ruang transisi/netral) untuk laki-laki dan perempuan, dan (3) goah dan pawon (ruang belakang untuk wanita) (Heryana, 2010: 372-373). Sementara itu, pembagian ruang pada perumahan karyawan perkebunan tidak mengadopsi filosofi Sunda tersebut.

Pola perkampungan orang Sunda memiliki ciri khas tersendiri, yaitu pola memanjang dan memusat dengan pusat rumah ketua adat (рupuhu) di ujung jalan. 
Pola ini dapat dijumpai pada perkampungan masyarakat Baduy di Banten dan Kampung Naga Tasikmalaya di Jawa Barat (Nuralia, 2020: 83).

Konsep dasar arsitektur tradisional Sunda adalah harmoni dengan alam. Sebutan bumi untuk rumah tinggal, penataan rumah melingkar memanjang membentuk huruf U, memiliki makna berkumpul (ngariung). Rumah dibangun sederhana membujur dari timur ke barat, menyesuaikan dengan peredaran sinar matahari dan tidak menentang hukum alam. Keadaan ini menjadi sangat baik karena sirkulasi udara dan cahaya lancar dan berubah secara alamiah (Suharjanto 2014: 514).

Pola pemukiman rumah karyawan perkebunan dan rumah tradisional Sunda memiliki pola yang berbeda. Pola pemukiman rumah karyawan perkebunan berderet atau berjejer teratur, di atas lahan berkontur rata, dalam bentuk lahan persegi atau persegi panjang (Gambar 5 dan 7). Pola pemukiman seperti ini adalah hasil bentukan tangan manusia, sebagai bukti adanya persentuhan budaya Barat. Kontur lahan alam pegunungan yang tidak rata atau topografi permukaan tanah bergelombang, diubah dengan metode cut and fill. Persentuhan budaya barat dalam arsitektur rumah karyawan perkebunan menjadi gaya campuran yang sering disebut sebagai gaya Indis (Sukiman, 2011: 3).

Persentuhan budaya Barat pada Rumah Karyawan Perkebunan juga tanpak dalam struktur bangunan dan tata ruang dalam. Konsep modern Eropa dalam bentuk sederhana, tetapi tetap mengacu pada konsep form follows function, yaitu bentuk mengikuti fungsi, sebagai karakter yang cukup khas (Mayer 1992).

Lahan pemukiman pekerja Kebun Cinyiruan dahulu disebut Komplek Jejer Sapuluh. Sekarang bentuk lahan dan rumah sudah mengalami perubahan (Gambar 5). Bentuk rumah di Komplek Jejer Sapuluh yang masih dijumpai adalah bangunan rumah yang dibangun sekitar tahun 1960an (Jajang, Asisten Afdeling Tirtasari Perkebunan Kertamanah di Cinyiruan, 6 Juni 2019).

Perubahan bentuk rumah terutama tampak pada bentuk atap. Pada awalnya rumah karyawan Kebun Cinyiruan berbentuk atap julang ngapak. Kemudian ketika dilakukan perubahan di tahun 1960an, bentuk atapnya berubah menjadi atap jolopong dan atap parahu kumereb

Tabel 1. Model Rumah Tradisional Sunda dan Rumah Karyawan Perkebunan

\begin{tabular}{|c|c|c|c|c|c|}
\hline $\begin{array}{l}\text { Bangunan } \\
\text { Rumah }\end{array}$ & Model & $\begin{array}{l}\text { Pembagian } \\
\text { Ruang }\end{array}$ & $\begin{array}{l}\text { Struktur } \\
\text { Bangunan }\end{array}$ & $\begin{array}{l}\text { Tata Letak dalam Lanskap } \\
\text { Ruang Pemukiman }\end{array}$ & Bahan Bangunan \\
\hline $\begin{array}{l}\text { Tradisional } \\
\text { Sunda }\end{array}$ & $\begin{array}{l}\text { Rumah } \\
\text { Panggung }\end{array}$ & $\begin{array}{l}\text { Konsep Tri } \\
\text { Tangtu }\end{array}$ & $\begin{array}{l}\text { Konsep } \\
\text { Tri Tangtu }\end{array}$ & $\begin{array}{l}\text { Mengelompok, tidak rapih, } \\
\text { jarak antar rumah tidak sama, } \\
\text { permukaan lahan tidak rata } \\
\text { atau sesuai kontur tanah }\end{array}$ & $\begin{array}{l}\text { Kayu, bambu, } \\
\text { batu, daun- } \\
\text { daunan, } \\
\text { penggunaan pasak } \\
\text { kayu untuk } \\
\text { sambungan. }\end{array}$ \\
\hline
\end{tabular}

\begin{tabular}{|c|c|c|c|c|c|}
\hline $\begin{array}{l}\text { Karyawan } \\
\text { Perkebunan }\end{array}$ & $\begin{array}{l}\text { Rumah } \\
\text { Panggung }\end{array}$ & $\begin{array}{l}\text { form } \\
\text { follows } \\
\text { function }\end{array}$ & $\begin{array}{l}\text { Morfologi } \\
\text { Tubuh } \\
\text { Manusia }\end{array}$ & $\begin{array}{l}\text { Mengelompok, tertata rapih, } \\
\text { jarak antar rumah sama, } \\
\text { permukaan lahan rata dengan } \\
\text { metode } \text { cut \& fill }\end{array}$ & $\begin{array}{l}\text { Kayu, bambu, } \\
\text { batu, genteng } \\
\text { tanah liat, } \\
\text { penggunaan pasak } \\
\text { kayu untuk } \\
\text { sambungan. }\end{array}$ \\
\hline Perkebunan & Permanen & $\begin{array}{l}\text { Model } \\
\text { Victorian } \\
\text { yang } \\
\text { komplek }\end{array}$ & Morfologi & $\begin{array}{l}\text { Terpisah, terencana dengan } \\
\text { baik, gaya arsitektur khusus, } \\
\text { permukaan lahan rata di atas } \\
\text { pedataran puncak bukit dengan }\end{array}$ & $\begin{array}{l}\text { Bata merah, batu } \\
\text { andesit, kayu, } \\
\text { kaca, genteng } \\
\text { tanah liat dan atap }\end{array}$ \\
\hline
\end{tabular}


(Gambar 5). Bentuk atap yang digunakan masih merupakan atap tradisional Sunda. Dengan demikian, ada kearifan lokal yang masih dipertahankan dan menjadi identitas rumah karyawan perkebunan.

Lanskap budaya industri perkebunan juga tampak dalam tata guna lahan pertanian, yaitu kebun, sawah, dan ladang. Ketiga lahan tersebut menjadi sumber pemenuhan kebutuhan hidup sehari-hari atau ekonomi subsisten. Para pekerja menjalankan kesehariannya bekerja sebagai buruh kebun dan pabrik, kemudian menggarap lahan yang ada di sekitar rumahnya atau lahan kosong tidak jauh dari tempat tinggalnya. Biasanya mereka bercocok tanam sayuran dan palawija, bersawah atau menanam padi basah, serta berladang atau menaman padi huma. Selain itu, mereka juga beternak unggas untuk memenuhi kebutuhan protein sekeluarga. Sementara itu, tata guna lahan sebagai area tanaman komersial atau perkebunan kina merupakan konsep ekonomi modern kaum koloni (Barat/Belanda). Pohon kina ditanam di lahan miring seperti di lereng gunung atau lereng bukit. Lahan perkebunan tersebut menjadi produksi utama yang menghasilkan tanaman komersial yang laku di pasaran dunia. Tanaman kina pernah menjadi primadona di awal abad ke-20, hampir $90 \%$ kebutuhan kina dunia dipasok dari Hindia Belanda.

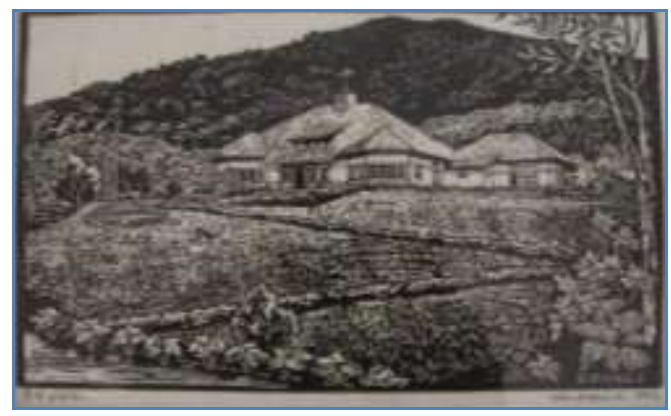

Gambar 9. Lukisan Tangan Rumah ADM Perkebunan Cinyiruan Masa Kolonial (1942)

Sumber: Rumah Dinas ADM Perkebunan Kertamanah, 2019.
Lanskap budaya industri perkebunan juga menampakkan lahan pemukiman utama, yang berada di pedataran lereng dengan halaman luas dan berlatar belakang kebun kina di lereng gunung atau bukit. Penempatan ini sangat direncanakan dan ditata dengan baik, karena diperuntukkan bagi pejabat tertinggi perkebunan ketika itu, yaitu rumah tinggal administratur, seperti tampak dalam gambar lukisan (Gambar 9).

Rumah administratur perkebunan Kina Cinyiruan dahulu (sekarang Rumah Dinas Perkebunan Kertamanah), berada di puncak bukit dengan pemandangan ke lahan komplek pabrik, perumahan karyawan Jejer Sapuluh, dan perkantoran. Posisi tersebut sangat strategis dalam menjalankan fungsi pengawasan dan fungsi pengelolaan. Pemerintah kolonial membentuk lanskap alam yang bertujuan untuk menopang berbagai kepentingan mulai dari keletakan lanskap hingga keberlangsungan proses produksi. Hal tersebut merupakan bagian dari proyek negara yang disebut sebagai rekayasa sosial. Masyarakat dibentuk atas logika rasional pengetahuan dalam skema perencanaan yang ilmiah (Scott, 1998).

Kaum koloni atau para pengusaha perkebunan dengan sengaja memanfaatkan budaya lokal para pekerja perkebunan. Hak ini menjadi sangat menguntungkan untuk membuat mereka nyaman, bekerja giat, dan tinggal menetap di perumahan perkebunan yang disediakan perusahaan. Demikian juga dengan rumah tinggal pejabat tinggi perkebunan, menempati lahan yang paling strategis, akses keluar masuk mudah memiliki jalur jalan tersendiri. Hal ini terlihat dari Rumah Dinas Administratur Perkebunan Cinyiruan (Gambar 5 dan Gambar 9) yang memiliki jalan masuk kendaraan roda empat dan tangga naik untuk pejalan kaki. Selain itu, jalan masuk ke perkebunan kina tersendiri di bagian belakang rumah.

Rumah administratur tersebut juga dilengkapi berbagai fasilitas keseharian yang sengaja diadakan. Selain bangunan 
inti, ada bangunan tambahan (ruang service) dan bangunan mes (untuk menerima dan menginap tamu dari luar). Bangunan inti diperuntukkan bagi administratur dan keluarga, bangunan tambahan untuk kamar para pembantu, dan kebutuhan pelayanan. Dalam hal ini, tampak nilai budaya kolonial yang memberi ruang hidup layak bagi para pembantu rumah tangga dan pekerja lainnya.

Rumah administratur perkebunan Cinyiruan tersebut menjadi model rumah dengan arsitektur khas Eropa di perkebunan, atau bangunan kolonial perkebunan. Berdasarkan pengamatan di lapangan, model dan gaya bangunan arsitektur Eropa identik dengan kesan modern, megah, klasik, gothic, serta warna yang lembut, cerah, dan hangat, seperti Victoria Style. Desain secara visual eksterior cukup komplek dan detail. Dinding rumah tebal, pintu dan jendela berukuran besar, serta bentuk bangunan menjulang tinggi.

Bangunan khas Eropa tersebut juga memiliki permukaan lantai yang ditinggikan dari permukaan tanah. Terdapat anak tangga untuk mencapai teras dan pintu masuk utama. Selain itu, pintu masuk utama dilengkapi dengan pintu masuk tambahan di samping kiri dan kanan serta di bagian belakang rumah. Halaman cukup luas di sekeliling rumah dengan kolam ikan, tanaman hias pendek, dan pohon tinggi peneduh. Pintu gerbang masuk dari jalan raya atau jalan perkebunan lebih dari satu akses. Ada jalan lebar untuk kendaraan roda empat dan ada jalan setapak beranak tangga untuk jalan orang.

Bangunan rumah dinas administratiur perkebunan Cinyiruan (sekarang Kertamanah) merupakan bangunan rumah ADM yang kedua. Bangunan ini memiliki gaya arsitektur transisi modern Eropa (Hartono dan Handinoto, 2006). Gaya Eropa dipadu dengan lokal dengan penyesuaian iklim tropis basah Indonesia di alam pegunungan
Priangan Jawa Barat. Penetapan ini berdasarkan pendirian bangunan yang diperkirakan didirikan antara akhir abad ke-19 sampai awal abad ke-20, di era peralihan dari gaya Empire (Indische Empire Stijl) ke gaya Indo Eropa (IndoEuropean Stijl) atau kolonial modern. Perubahan gaya ini diawali dengan perubahan sosial yang terjadi di masyarakat Hindia Belanda ketika itu. Modernisasi penemuan baru di bidang teknologi ${ }^{2}$ dan kebijakan politik kolonial ${ }^{3}$.

Visual interior atau tata ruang dalam bangunan rumah administratur perkebunan Cinyiruan juga menunjukkan kesan rumit dan detail. Bangunan yang terdiri dari dua bagian (inti dan ruang service) serta bangunan mes yang menempel di bangunan inti tersebut, memiliki tata ruang dalam khas rumah hunian dengan detail ruang tertentu. Ruang utama atau ruang tamu berpadu dengan ruang tengah dengan persinggungan batas ruang. Kemudian ruang kamar tidur utama dan kamar tidur anak memiliki posisi yang berlawanan atau sejajar dengan lorong sebagai penghubung. Kemudian ruang makan berpadu dengan ruang dapur (dapur bersih). Hampir setiap ruangan memiliki keterhubungan melalui connecting door. Sementara itu, bangunan tambahan sebagai ruang service, terdiri dari banyak ruang seperti dapur (dapur kotor), kamar tidur pembantu, ruang cuci setrika, WC, gudang, dan ruang serba guna

2 Seperti listrik, telepon, telegram, serta kendaraan bermotor yang mulai marak digunakan di Hindia Belada di awal abad ke20, terutama di kota-kota besar, seperti Batavia, Bandung, Semarang, Surabaya, dan lain sebagainya (Hartono dan Handiboto, 2006: 81). Termasuk di perkebunan di Bandung Selatan, seperti Perkebunan Cinyiruan dan Kertamanah mulai menggunakan kendaran bermotor roda empat, khusus bagi para pejabat tinggi perkebunan.

${ }^{3}$ Lahirnya UU Agraria 1870, dicanangkannya Politik Etis 1901, diberlakukannya UU Desentralisasi 1905 (Hartono dan Handiboto, 2006: 81). 
lainnya. Selanjutnya bangunan mes untuk tamu memiliki pembagian ruang yang hampir sama dengan bangunan inti. Kondisi ini menunjukkan masih adanya gaya arsitektur era Indische Empire Stijl dengan model Victorian baru yang rumit dan detil.

Bahan bangunan rumah administratur tersebut lebih memanfaatkan bahan yang tersedia di lingkungan alam sekitarnya. Di antaranya bahan kayu, bata merah, dan batu andesit (batu kali), serta bahan atap sirap. Kelengkapan bahan penutup jendela berupa kaca adalah bahan modern yang mempercantik bangunan dan pemenuhan kebutuhan akan penerangan alami dari cahaya matahari yang masuk menembus kaca.

Selain ruang permukiman, ruang produksi di pabrik dan di kebun, juga ada ruang pendukung produksi dan ruang fasilitas sosial atau fasilitas umum. Ruang pendukung produksi memuat bangunan pendukung produksi, seperti gudang, PLTA, dan bangunan serba guna lainnya. Kemudian ruang fasilitas umum atau fasilitas sosial terdiri dari pasar, sekolah, tempat ibadah (masjid), poliklinik, posyandu, pemakaman. dan sarana olah raga (lapang tenis).

Bangunan-bangunan

fasilitas

perusahaan tersebut memberi kemudahan dan pemenuhan kebutuhan keseharian. Para pemilik dan pengelola (pejabat/unsur pimpinan) dan karyawan (para pekerja administrasi dan tenaga kasar/buruh), memiliki hak untuk memanfaatkan fasilitas-fasilitas tersebut. Kehidupan keseharian akan pangan, sandang, dan papan terpenuhi dengan optimal. Keadaan ini menunjukkan nilai kemajuan kolonialisme Barat di Indonesia.

Kina tumbuh baik di lahan miring pada punggungan gunung atau bukit menghadap ke Barat. Menurut pengelola perkebunan, kina tidak terlalu membutuhkan sinar matahari, sehingga lereng Barat menjadi pilihan tepat untuk pencahayaan pohon menuju cahaya sore (Gambar 10).

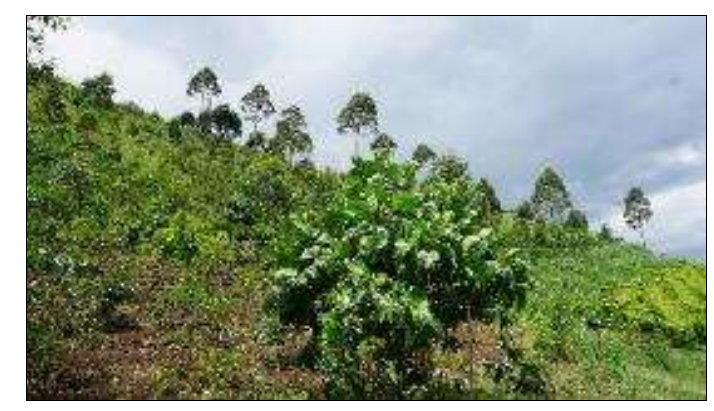

Gambar 10. Bekas Kebun Kina Cinyiruan. Dok. Balai Arkeologi Jawa Barat, 2019.

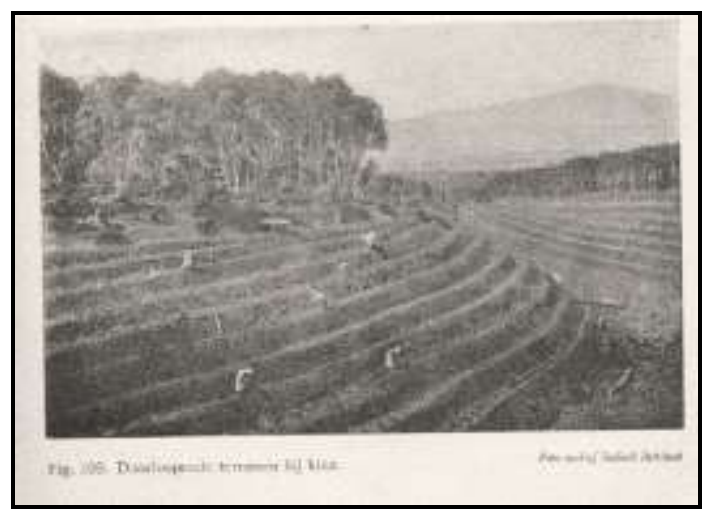

Gambar 11. Lanskap Kebun Kina Pada Lahan Miring Berterasering

Sumber: Archief Indish Instituut dalam Van Gall en C. Van De Koppel, Deel 1, 1946.

Pada zaman Belanda penanaman kina juga menyesuaikan dengan kebutuhan karakteristik pohon kina. Lereng bukit yang berkontur miring sekitar 30-45 ditata dengan undakan-undakan tanah atau terasering (Gambar 11). Lahan seperti ini memudahkan penanaman dan pemeliharaannya. Para pekerja akan mengikuti kontur tanah melingkar lereng bukit atau lereng gunung, yang telah ditata dengan teras-teras tersebut.

Lokasi perkebunan kina dalam lanskap industri perkebunan menjadi sangat penting. Tanaman produksi utama di Perkebunan Cinyiruan pada masa kolonial sangat diperhatikan dan dijaga pertumbuhannya untuk menghasilkan kulit kina yang sesuai dengan kebutuhan ekspor, kualitas tinggi, dan menghasilkan zat quinine yang berkualitas. Selain memudahkan penanaman dan perawatan, 
juga akan memudahkan pemanenan dan pengangkutan hasil panen ke lokasi pabrik.

Pada zaman dahulu hasil panen kulit kina basah dari kebun tidak diangkut manual dengan kendaraan, tetapi bisa langsung menuju lokasi pabrik (penjemuran) dengan lori kereta gantung. Menurut penuturan pengelola perkebunan, dahulu ada lori kereta gantung dari puncak bukit kebun kina menuju pabrik, sehingga memudahkan dan mempercepat penerimaan kulit kina basah di tempat penimbangan untuk kemudian masuk ruang penjemuran (Jajang, wawancara, Juni 2019).

Perkembangan lebih lanjut terjadi dengan keberadaan kendaraan roda empat untuk mengangkut hasil panen. Kulit kina basah yang sudah diikat dan dimasukkan ke dalam karung akan diangkut ke pabrik dengan truk. Selanjutnya alat angkut kulit kina juga bisa dilakukan dengan menggunakan sepeda motor dan angkutan tradisional (Permana, wawancara, Juni 2018; Hidayat, wawancara, Juli 2019). Alat angkut tradisional dengan cara dipikul di pundak secara manual yang dilakukan oleh para pekerja dengan menggunakan "rancatan" kayu dengan wadah "tolombong" terbuat dari bambu atau menggunakan karung yang diikat di kedua ujung "rancatan" tersebut. Pengangkutan tersebut terutama dari kebun kina yang berjarak dekat dengan pabrik dan kulit kina sudah dikumpulkan di satu titik di tepi jalan perkebunan.

Keberadaan jalan perkebunan dan ruang kebun yang diperuntukkan sebagai jalur lalu lintas lori kereta gantung, menunjukkan adanya ruang budaya yang berfungsi ganda. Jalur lori kereta gantung bermula dari lahan kebun melintasi ruang permukiman dan ruang lainnya sehingga sampai di pabrik. Kemudian jalur jalan perkebunan tidak hanya sebagai ruang mobilitas para pekerja dan pengelola, tetapi juga lalu lintas bahan produksi utama, yaitu kulit kina kering dari kebun menuju pabrik.
Pohon kina dapat tumbuh sampai ketinggian maksimal sekitar 15 meter dari permukaan tanah. Pohon-pohon kina yang usianya sudah puluhan tahun tersebut menjadi pohon biji yang akan menumbuhkan pohon-pohon baru, setelah melalui proses tertentu. Lahan kebun kina membutuhkan lahan terbuka luas, seperti halnya hutan belantara, tetapi tetap terpelihara dan tidak dibiarkan tumbuh pohon-pohon lain yang akan mengganggu pertumbuhan kina itu sendiri. Ada beberapa pohon pendamping dan pelindung, seperti pohon damar dan pohon kayu putih. Juga ada beberapa pohon lain di luar batas lahan kebun kina.

\section{PENUTUP}

Lanskap budaya industri perkebunan kina Cinyiruan merupakan ruang permukiman dan perkebunan, dengan tata guna lahan yang terbagi ke dalam beberapa bagian sesuai fungsinya. Ruang permukiman terdiri dari lahan komplek pabrik, lahan perkantoran, lahan perumahan karyawan, lahan fasilitas sosial atau fasilitas umum, lahan sarana olah raga, serta lahan rumah tinggal pejabat tinggi perkebunan.

Lahan kebun untuk keperluan hidup sehari-hari para pekerja, di samping keberadaan pasar yang siap menyediakan berbagai keperluan. Kemudian lahan perkebunan menjadi lahan produksi utama, yaitu produksi kina, yang bersifat komersial dengan penataan modern barat. Tata guna lahan pada lanskap budaya industri perkebunan tersebut tidak hanya menjadi ruang budaya fisik, tetapi juga memiliki nilai budaya yang bersifat non fisik. Pertama, nilai budaya tradisional Sunda sebagai kearifan lokal dalam harmoni dengan alam. Kedua, nilai budaya kolonial dari perspektif kolonialisme Barat 


\section{DAFTAR SUMBER}

Archief Indish Instituut dalam Van Gall en $C$. Van De Koppel, Deel 1, 1946.

Album foto "Pictures From The Archives of The Royal Tropical Museum Amsterdam" di Rumah Manajer / ADM Perkebunan Kertamanah.

Boeke, J. H. (1983). Prakapitalisme Di Asia. Terjemahan D. Projosiswoyo. Jakarta: Yayasan Sinar Harapan bekerja sama dengan Yayasan Tani Atsiri Wangi.

Casella, E. C. (2005). "Social Workers: New Diretions in Industrial Archaeology". Dalam Eleanor Conlin Casella and James Symonds (Edited), Industrial Archaeology: Future Directions. USA: Springer Science and Business Media Inc. p. 3-32.

Danasasmita, S., Ayatrohaedi., Wartini, T., Darsa, U. A. (1987). Sewakadarma, Sanghyang Siksakandang Karesian, Amanat Galunggung: Transkripsi dan Terjemahan. Bandung: Bagian Proyek Penelitian dan Pengkajian Kebudayaan Sunda (Sundanologi) Ditjen Kebudayaan Depdikbud.

Daniel, M. (2004). Pengantar Ekonomi Pertanian. Jakarta: Bumi Aksara.

Foster, G. M. (1975). Traditional Society and Technical Change, Harper \& Row Publisher, New York-Evanston-San Fransisco-London.

Foth, H. D. (2010). Dasar-Dasar Ilmu Tanah. Terjemahan Soenartomo Adisoemarto.

Hartono, S. dan Handinoto. (2006). Arsitektur Transisi di Nusantara dari Akhir Abad Ke-19 ke Awal Abad Ke-20 (Studi Kasus Komplek Bangunan Militer di Jawa pada Peralihan Abad 19 ke 20). Dalam Dimensi Teknik Arsitektur Vol. 34 No. 2, Desember 2006. Halaman 81-92.

Harvey, R. R. and S. Buggey. (1988). Historic Landscape section 630. C. W. Harris and N. T. Dines, editor. Time Saver Standards For Landscape Architecture. New York: Mc Graw-Hill Book Co.

Heryana, A. (2010). Tri Tangtu di Bumi di Kampung Naga: Melacak Sistem
Pemerintahan (Sunda). Patanjala Vol. 2, No. 3, September 2010: 359 - 376.

Hidayat, T. (Juni, 2018). Wawancara.

Hidayat, T. (Juli, 2019). Wawancara.

Imadudin, I. (2021). Laporan Survei Kanal Budaya "Cerita Kina dari Bumi Pasundan". Bandung: BPNB Provinsi Jawa Barat.

Jajang. (Juni, 2019). Wawancara.

Kartodirdjo, S. \& Surjo, D. (1991). Sejarah Perkebunan di Indonesia: Kajian Sosial Ekonomi. Yogyakarta: Aditya Media.

Lanskap Budaya. (2018, 13 November). http://borobudurpedia.id/lanskap-budaya/.

Mayer, B. 1992. The Complete Book of Interior Design. Australia: Simon and Schuster Ltfd

Nuralia, L. (2020). Model Rumah dan Kearifan Lokal Rumah Karyawan Perkebunan Zaman Belanda di Bandung Jawa Barat. Prosiding Seminar Evaluasi Hasil Penelitian Arkeologi (EHPA) Tahun 2019. Kementerian Pendidikan dan Kebudayaan Badan Penelitian dan Pengembangan dan Perbukuan Pusat Penelitian Arkeologi Nasional. Cetakan Pertama, November 2020.

Nuralia, L. \& Imadudin, I. (2020). Simbol Kuasa dan Nilai Budaya dalam Tinggalan Arkeologi Kolonial di Perkebunan Teh Sedep Kabupaten Bandung. Patanjala Vol. 12 No. 2 Oktober 2020: 177-193.

Nuralia, L. \& Imadudin, I. (2019). Kebudayaan Hibrid Masa Kolonial di Perkebunan Batulawang Banjar. Patanjala Vol.11 No.1, Maret 2019.

Nuralia, L., Saptono, N., Hermawan, I., Wulandari, R., Pamumpuni, A., Widarwanta, Hidayat, D., Saripudin, D., Montana, F. (2019). Laporan Penelitian Arkeologi. Bangunan Industri dan Produksi Perkebunan Kina Kabupaten Bandung Barat dan Sekitarnya, Provinsi Jawa Barat, Abad XIX - XX Masehi. Bandung: Balai Arkeologi Jawa Barat.

Nuralia, L. (2016). Situs Perkebunan Cisaga 1908-1972: Kajian Arkeologi Industri tentang Kode Budaya Kolonial. Tesis 
Fakultas Ilmu Pengetahuan Budaya, Program Studi Magister Arkeologi, UI.

Nurisjah, S. dan Pramukanto, Q. (2001). Perencanaan Kawasan untuk Pelestarian Lanskap dan Taman Sejarah. Program Studi Arsitektur Lanskap, Jurusan Budidaya Pertanian, Fakultas Pertanian. Bogor: IPB. 49p (tidak dipublikasikan).

Nuryanto \& Ahdiat, (2014). Kajian Hubungan Makna Kosmologi Rumah Tinggal Antara Arsitektur Tradisional Masyarakat Sunda dengan Arsitektur Tradisional Masyarakat Bali (Penggalian Kearifan Lokal menuju Pembangunan Berbasis Konsep Bangunan Hijau). Seminar Nasional Arsitektur Hijau. Denpasar: Universitas Warmadewa.

Palmer, M. \& Neaverson, P. (2000). Industrial Archaeology, Principles and Practice. London and New York: Routledge.

Permana, Ervi. (Juni 2018). Wawancara.

Peta Topografi Blad 32 B (Alg. No. XL 38-B) Java. Res. Preanger Regentschappen. Topografischen Dienst in 1919 - 1923. Dutch Colonial Maps - Leiden University Libraries.

Peta Topografi Blad 32 B/Alg. No. XL 38-B, 1919 - 1923., n.d. Jakarta: ANRI.

Peta Topografi sheet. (1944). No. 39/XL-C., A.M.S

Publicatie Zonder Vermelding LUCHTOPNAME K.N.I.L.M. VERBODEN 938

Ramadhan. (Maret, 2021). Wawancara.

Regerings Almanak Voor Nederlandsch-Indie, 1880, 1892, 1893,1900, 1901, 1902, 1906. Jakarta: ANRI

Suharjanto, G. (2014). Konsep Arsitektur Tradisional Sunda Masa Lalu dan Masa Kini. Jurnal Comtech, Vol. 5 (1), 505521.

Sajogyo (Ed). (1982). Bunga Rampai Perekonomian Desa. Jakarta: Yayasan Obor Indonesia dan Yayasan Agro Ekonomika.

Scott, J. C. (1998). Seeing Like a State: How Certain Schemes to Improve the Human Condition Have Failed. New Haven
(Amerika Serikat) dan London (Inggris): Yale University Press.

Sukiman, D. (2011). Kebudayaan Indis, Dari Zaman Kompeni Sampai Revolusi. Depok: Komunitas Bambu.

van Hall, C.J.J en C.Van De Koppel. (1946). De Landbouw In Den Indischen Archipel Deel 1, In drie deelen. Algemeen Gedelte, MCMXLV. 